\title{
Toxic Trace Metals and Pathological Changes in Organs of Rats Fed with Extract of Polluted Grasses
}

\author{
T. A. Modise*, M. L. Mpholwane**, C. Baker*** and J.O. Olowoyo*† \\ *Department of Biology, School of Science and Technology, Sefako Makgatho Health Sciences University, \\ Pretoria, South Africa \\ **Department of Physiology, School of Science and Technology, Sefako Makgatho Health Sciences University, \\ Pretoria, South Africa \\ ***Electron Microscope Unit, Sefako Makgatho Health Sciences University, Pretoria, South Africa \\ †Corresponding author: J.O. Olowoyo; joshua.olowoyo@smu.ac.za
}

Nat. Env. \& Poll. Tech.

Website: www.neptjournal.com

Received: 06-08-2019

Revised: $03-09-2019$

Accepted: 07-11-2019

\section{Key Words:}

Rats

Pathological changes

Trace metals

Polluted grasses

\begin{abstract}
The present study investigated the pathological effects of trace metals in organs of Wistar rats fed with extracts of grasses collected from areas surrounding mining industries. The rats were examined for clinical signs during the experimental period and the concentration of trace metals in organs was examined using ICP-MS. The kidneys were analysed for pathological changes under Transmission Electron Microscopy (TEM). Generally, trace metal concentration in the organs of the rats followed the order $\mathrm{Zn}>\mathrm{Cu}>\mathrm{Mn}>\mathrm{As}$. These trace metals were bio-accumulated more in the spleen than kidneys and livers. Clinical signs such as hair loss, reduced fluid intake, pale ears and feet and skin irritation were observed. TEM investigation of kidney glomeruli showed pathology such as the presence of mesangial deposits, as well as the villous formation and effaced foot processes of the podocytes. Trace metals were bioaccumulated in the organs of the rats and spleen had a higher concentration, which might have negative effects on the organs. It was concluded from the study that plants harvested from polluted sites might be harmful when consumed as they have the potential to induce organ dysfunction.
\end{abstract}

\section{INTRODUCTION}

Developing countries are facing serious issues concerning pollution due to economic growth and various developmental projects, leading to increased concentrations of trace metals in the environment (Jan et al. 2015). The increased level of trace metals in the environment through vehicle exhausts, solid waste disposal, application of sludge, irrigation of wastewater and atmospheric deposition from industries has been experienced by many countries (Qu et al. 2012). China has also shown rapid development, resulting in serious trace metal pollution in their environment (Hu et al. 2014). In South Africa, the studies by Olowoyo et al. (2013) identified different mining activities as a potential source of trace metals in the environment, whereas, Okonkwo et al. (2009) have reported on vehicular activities as a source of trace metals in the urban soils of Pretoria, South Africa. Tshwane (Pretoria) has also been reported as a region in South Africa that has poor air quality due to the trace metal contaminants released by mining industries around the area (Writer 2016). Pollution of the environment by trace metal concentrations is of great concern due to their non-degradable nature and persistent characteristics as this can place risk on the ecosystem (Jan et al. 2015). These trace metals find their way into human and other mammalian systems through plant uptake from either soil or water, which are then consumed and integrated into their bodies (Durkalec et al. 2014).

Various studies have shown that the human body can become exposed to a significantly elevated concentration of trace metals through different pathways (Stankovic et al. 2014). The most important route into mammalian systems is through inhalation of particulate matters, dermal contact with substances which are likely to cross the skin barrier, as well as ingestion of plants grown in soil contaminated by trace metals or irrigation by water containing trace metals (Moreira et al. 2005, Soewu et al. 2014). The exposure of animals and humans to trace metals can cause progressive and irreversible accumulation in the organs (Baby et al. 2010). Besides, the intake and uptake of trace metals by the body produce numerous interactions because of metabolism and its regulation (Wang et al. 2012). Manganese (Mn) is an essential element that is involved in various metabolic processes such as blood clotting, mineralization of the bones and production of adenosine phosphate (Markiewicz-Gorka et al. 2015). However, in excess Mn affects the optimal functioning of 
arteries, heart, nervous system and liver of mammals (WHO 2011, Markiewicz-Gorka et al. 2015). Similarly, zinc (Zn) is known to be responsible for an increase in oxidative stress produced by exposure to lead (Pd) and cadmium (Cd), but in excess, it may cause many side effects in humans such as inadequate diet, irritability, sickle cell disease, tiredness and diarrhoea (Zhai et al. 2015).

The impact of trace metals on mammalian organs has been studied (Mohapatra et al. 2009). Histological examination of albino rats from a busy road site exhibited damage to internal organs such as kidney, liver, heart, and lungs due to the exhaust fumes of cars having a great impact on their physiology (Ajayi et al. 2011). Li et al. (2015) also studied the impact of trace metal bioaccumulation in kidneys and livers of rats and reported that trace metal bioaccumulation causes inflammation in these organs and the occurrence of melanomacrophage centres (aggregates of highly pigmented phagocytes) in the spleen (Arantes et al. 2015). Notably, effects from trace metals in these studies are however exaggerated as they were established by acute or sub-chronic exposures that do not reproduce the actual risk to the general population (Markiewicz et al. 2015). Most of the study carried out on the impact of trace metals on the organs of mammals were carried out using the plants that might seem difficult to consume by the mammals used in the study, as they were not in their natural habitat. The present study used an extract from these polluted grasses to feed the rats used in this study as against the use of the whole grass. Our study therefore in an attempt to duplicate the natural state seeks to establish and examine the levels of toxic trace metals and their pathology in organs of rats fed with an extract of grass collected from areas adjacent to mining sites. The present study also uses TEM (Transmission Electron Microscope) to determine the actual impact on the organs of the rats used in this study.

\section{MATERIALS AND METHODS}

\section{Study Design}

Approval to conduct the research and experimentation on animals was sought from the Research Ethics Committee and the Animal Ethics Committee of the Sefako Makgatho Health Sciences University before the commencement of the study. The study was conducted during February 2017-January 2018 at Sefako Makgatho Health Sciences University, Pretoria, South Africa. All the procedures performed in this study were following the Institutional Animal Care and Use Committee (IACUC) ethical guidelines. A total of thirty three-month old rats (15 adult males and 15 adult females) were obtained from the South African Vaccine Producers, Kempton Park, Gauteng and acclimatized for two weeks, whereafter they were randomly divided into three groups of 10 (five each males and females). Rats in the experimental group were fed with commercial cubes (mice/rat cubes, Epol $^{\mathrm{TM}}$ ) and $40 \mathrm{~mL}$ of water supplemented with $200 \mathrm{mg} /$ $\mathrm{kg}$ of the extract obtained from different grasses (Cynodon dactylon, Hyparrhenia hirta and Urochloa mosambicensis) collected from two mining sites. In addition, the third group (control) was fed with only water and commercial rat cubes. This study was conducted for 28 days and clinical signs were observed throughout the experimental period. The rats were kept individually in polycarbonate cages $(50 \mathrm{~cm} \times 32 \mathrm{~cm})$ in a well-ventilated animal room $\left(22^{\circ} \mathrm{C}-25^{\circ} \mathrm{C}\right)$ kept at a 12 $\mathrm{h}$ light/12 h dark cycle. Their beddings were lined with vermiculite that was regularly replaced, and PVC pipe provided for enrichment purposes.

After the experimental period, the rats were restrained by using the scruff method and euthanized with $0.2 \mathrm{~mL}$ of Euthapent solution (pentobarbitone sodium), and thereafter the ventral side of the rat was exposed. A solution of $70 \%$ ethanol was used to prepare an area on the ventral side followed by the insertion of a $23 \mathrm{G}$ needle at $30^{\circ} \mathrm{C}$ from the horizontal axis of the sternum to the heart where after 4.5 $\mathrm{mL}$ blood was collected. Blood was collected into pre-cooled serum-separating tubes (SST) and yellow-topped containing acid citrate dextrose (ACD). Thereafter, the chests of rats were exposed and organs (kidneys, liver and spleen) were dissected and rinsed with saline to remove excess blood and clots.

\section{Preparation of the Grass Extract}

The aerial parts of the grasses were dried in an oven at $40^{\circ} \mathrm{C}$ for 72 hours and equivalent quantities of the grasses $C$. dactylon, H. hirta and U. mosambicensis $(5 \mathrm{~g}: 5 \mathrm{~g}: 5 \mathrm{~g})$ was then mixed with $150 \mathrm{~mL}$ distilled water. The solution was ultrasonicated for 60 minutes under ice, followed by the addition of $150 \mathrm{~mL}$ warm distilled water $\left(50^{\circ} \mathrm{C}\right)$. Stirring commenced for 60 minutes using a magnetic stirrer; left for 24 hours to sediment where after the supernatant was filtered, dried at $40^{\circ} \mathrm{C}$ and stored at $4^{\circ} \mathrm{C}$ until further use.

\section{Trace Metal Analysis of Grasses, Grass Extracts and Organs}

The grass samples were oven-dried for $48 \mathrm{hrs}$ at $70^{\circ} \mathrm{C}$ and ground using pestle and mortar. The ground grass samples and extracts were then digested using $2 \mathrm{~mL}$ of nitric acid and $3 \mathrm{~mL}$ of perchloric acid (Lion et al. 2016), followed by trace metal analysis using ULTIMA Inductively Coupled Plasma Mass Spectrometry (ICP-MS) (Olowoyo et al. 2011).

The organs (liver, spleen and kidneys) were cut into small pieces, and oven-dried at $50^{\circ} \mathrm{C}$ for five days. The dried organs 
were ground using a pestle and mortar and sieved to obtain homogenized particles; thereafter $0.5 \mathrm{~g}$ of each of the organs was placed in a pre-washed Erlenmeyer flask. The same volume of extract was transferred to separate conical flasks, and $3 \mathrm{~mL}$ nitric acid (55\%) was added to fresh samples and left to stand for 10 minutes. The solution was digested at $70^{\circ} \mathrm{C}$ for approximately $90 \mathrm{~min}$. During digestion, the samples were treated with an additional $2 \mathrm{~mL}$ nitric acid and 1 $\mathrm{mL}$ distilled water (to prevent the samples from drying out) while heating on a hot plate until all samples were dissolved and a clear solution was obtained. The digested solution was transferred into a $50 \mathrm{~mL}$ volumetric flask and filled with distilled water, filtered and stored at $4^{\circ} \mathrm{C}$ to be analysed for trace metal content ICP-MS. Quality assurance was guaranteed by analysing plant and organ samples in triplicate, followed by the analysis of CRM042 that contain trace metals.

\section{Liver Enzyme Activity}

The blood samples were used to determine liver enzyme activity (ALT and AST). Samples were centrifuged at 3000 rpm for 10 minutes at $4^{\circ} \mathrm{C}$, and extracted serum was stored at $-80^{\circ} \mathrm{C}$ until required. The frozen serum was left to warm to room temperature, poured into cuvettes and analysed (Human Diagnostics Worldwide, Germany) using system clinical chemical reagents (Indiko ${ }^{\mathrm{TM}}$ plus, Thermo Scientific ${ }^{\mathrm{TM}}$ ).

\section{Kidney Pathology Analysis and Antioxidant Activity}

The kidneys were cut $\left(1 \mathrm{~mm}^{3}\right)$, fixed in $2.5 \%$ glutaraldehyde, routinely prepared for electron microscopy at the Electron Microscope Unit (Sefako Makgatho Health Sciences University) and viewed using a JEM 1010 Transmission Electron Microscope (JEOL, Japan).

The two antioxidant enzymes, i.e. catalase (CAT) and superoxide dismutase (SOD), as well as glutathione (GSH) were measured to determine kidney antioxidant activity. Tissue samples were prepared by homogenising $300 \mathrm{mg}$ in $2 \mathrm{~mL}$ phosphate buffer followed by centrifugation at 15000 $\mathrm{rpm}$ for $10 \mathrm{~min}$ at $4^{\circ} \mathrm{C}$. The supernatant was separated by enzyme-linked Immunosorbent Assay kit (Cloud-Clone Corp, Katy, TX 77494, USA) for CAT, GSH and SOD activity and assessed using a microplate reader (BioTek ELx800, USA).

\section{Statistical Analysis}

One way Analysis of Variance (ANOVA) was used to determine differences in kidney antioxidant level, liver enzymes and the concentration of trace metals. Statistical analysis was carried out using SPSS 24.0, where $p<0.05$ was considered statistically significant. The results are represented as mean $\pm \mathrm{SD}$.

\section{RESULTS}

\section{Concentration of Trace Metals in Pellets and Extract of Grasses Used in the Study}

The concentrations of trace metals in rat commercial pellets and grasses harvested from soils around mining areas are given in Table 1 . The concentration of $\mathrm{Zn}$ ranged from $23.00 \pm 0.34-67.00 \pm 1.08 \mathrm{mg} / \mathrm{kg} ; \mathrm{Cu} 4.73 \pm 0.16-9.50 \pm 0.20$ $\mathrm{mg} / \mathrm{kg}$; and Mn $24.01 \pm 0.15-342.00 \pm 3.50 \mathrm{mg} / \mathrm{kg}$. The highest concentration of trace metals was recorded in Urochloa mosambicensis. There was a significant difference $(\mathrm{p}<0.05)$ in the concentration of trace metals in the grasses. Furthermore, the concentrations of $\mathrm{Zn}(152.30 \pm 7.54 \mathrm{mg} / \mathrm{kg})$ and $\mathrm{Cu}$ $(25.67 \pm 0.83 \mathrm{mg} / \mathrm{kg})$ in pellets used for this study were higher than the concentration recorded for all grasses.

The mean concentration of trace metals in the extract of grasses from trace metal-polluted areas and tap water are given in Table 2. In extracts, the concentration of copper

Table 1: Trace metals concentration in commercial rat pellets and grasses harvested from the soil around mining areas.

\begin{tabular}{|c|c|c|c|c|}
\hline \multirow{2}{*}{ Groups } & \multirow{2}{*}{ Grasses } & \multicolumn{3}{|c|}{ Trace metals $(\mathrm{mg} / \mathrm{kg})$} \\
\hline & & $\mathrm{Cu}^{*}$ & $\mathrm{Mn} *$ & $\mathrm{Zn} *$ \\
\hline \multirow{3}{*}{ S1 } & C. dactylon & $6.20 \pm 0.13$ & $223.00 \pm 2.20$ & $23.00 \pm 0.34$ \\
\hline & U. mosambicensis & $9.10 \pm 0.21$ & $342.00 \pm 3.50$ & $67.00 \pm 1.08$ \\
\hline & H. hirta & $4.73 \pm 0.16$ & $24.73 \pm 0.23$ & $43.60 \pm 0.53$ \\
\hline \multirow{3}{*}{ S2 } & C. dactylon & $7.20 \pm 0.11$ & $262.00 \pm 3.60$ & $32.00 \pm 0.13$ \\
\hline & U. mosambicensis & $9.50 \pm 0.20$ & $295.00 \pm 6.20$ & $37.00 \pm 0.29$ \\
\hline & H. hirta & $6.77 \pm 0.05$ & $24.01 \pm 0.15$ & $42.76 \pm 0.51$ \\
\hline \multicolumn{2}{|c|}{ Commercial rat pellets } & $25.67 \pm 0.83$ & $197.90 \pm 3.61$ & $152.30 \pm 7.54$ \\
\hline
\end{tabular}

Grass from: Site 1 (S1) and Site 2 (S2)

* Significance of comparison means by ANOVA is indicated by $(\mathrm{p}<0.05)$ 
(Cu) ranged from $8.95 \pm 0.15 \mathrm{mg} / \mathrm{L}$ to $10.68 \pm 0.20 \mathrm{mg} / \mathrm{L}$; zinc (Zn) $71.29 \pm 1.03 \mathrm{mg} / \mathrm{L}$ to $73.00 \pm 1.06 \mathrm{mg} / \mathrm{L}$ and manganese (Mn) $93.86 \pm 1.18 \mathrm{mg} / \mathrm{L}$ to $125.40 \pm 1.46 \mathrm{mg} / \mathrm{L}$. The highest concentration of $\mathrm{Cu}$ and $\mathrm{Zn}$ was recorded from the tap water while $\mathrm{Mn}$ was recorded from site S2. It should also be noted that the concentration of $\mathrm{Cu}(24.86 \pm 0.10 \mathrm{mg} / \mathrm{L})$ and $\mathrm{Zn}$ $(73.00 \pm 1.06 \mathrm{mg} / \mathrm{L})$ in tap water was higher than the recorded concentrations from extracts.

\section{Daily Intake of Fluid in the Rats Used for the Study}

The results of the experiment for the daily fluid (water or extracts) intake of rats during the study period (Table 3 ) shows a decrease in the consumption rate when fed with grass extracts collected from sites S1 and S2, in comparison to the more stable intake of tap water by rats in the control group $(\mathrm{C})$ towards the end of week one and week five. During week 1, the intake of grass extracts collected from sites S1 and S2 was higher than the control group. However, intake of the grass extracts collected from S1 and $\mathrm{S} 2$ decreased in week five when compared to tap water (control group).

\section{Clinical Manifestation in Rats During the Study Period}

During the second week of the experiment, clinical signs such as pale ears were visible. However, in the third week, wounds around the eyes were also noticeable due to skin irritation. By the fourth week, the rats experienced skin irritation that resulted in wounds around the neck (Fig. 1).

\section{Concentration of Trace Metals in the Organs of Rats}

The concentration of toxic trace metals such as $\mathrm{Pb}, \mathrm{Hg}, \mathrm{Cu}$, $\mathrm{Mn}, \mathrm{Zn}$ and $\mathrm{As}$ in the spleen of the rats is given in Table 4. Concentration for Lead $(\mathrm{Pb})$ ranged from $0.41 \pm 0.01$ $0.53 \pm 0.02 \mathrm{mg} / \mathrm{kg}$; with $\mathrm{Hg} 0.18 \pm 0.02-1.33 \pm 0.33 \mathrm{mg} / \mathrm{kg}$ and As ranging from $0.69 \pm 0.02-1.11 \pm 0.11 \mathrm{mg} / \mathrm{kg}$. The concentration of trace metals obtained in spleen samples of rats from sites $\mathrm{S} 1$ and $\mathrm{S} 2$ were significant $(\mathrm{p}<0.05)$. The concentration of trace metals in the spleen of the rats from sites S1 and S2 was lower in comparison to the control (C) group.

Table 2: Mean concentration of trace metals in grass extracts and tap water.

\begin{tabular}{|llll|}
\hline \multirow{2}{*}{ Extracts } & \multicolumn{3}{c|}{ Trace metals concentrations $(\mathrm{mg} / \mathrm{L})$} \\
\cline { 2 - 4 } & \multicolumn{1}{c|}{$\mathrm{Cu}^{*}$} & $\mathrm{Mn} *$ & $\mathrm{Zn}$ \\
\hline Extracts of grass from S1 & $8.95 \pm 0.15$ & $93.86 \pm 1.18$ & $71.29 \pm 1.03$ \\
Extracts of grass from S2 & $10.68 \pm 0.20$ & $125.40 \pm 1.46$ & $71.70 \pm 0.94$ \\
Plain tap water & $24.86 \pm 0.10$ & $5.78 \pm 0.05$ & $73.00 \pm 1.06$ \\
\hline
\end{tabular}

Grass extracts from Site 1 (S1) and Site 2 (S2)

* Significance of comparison means by ANOVA is indicated by $(\mathrm{p}<0.05)$
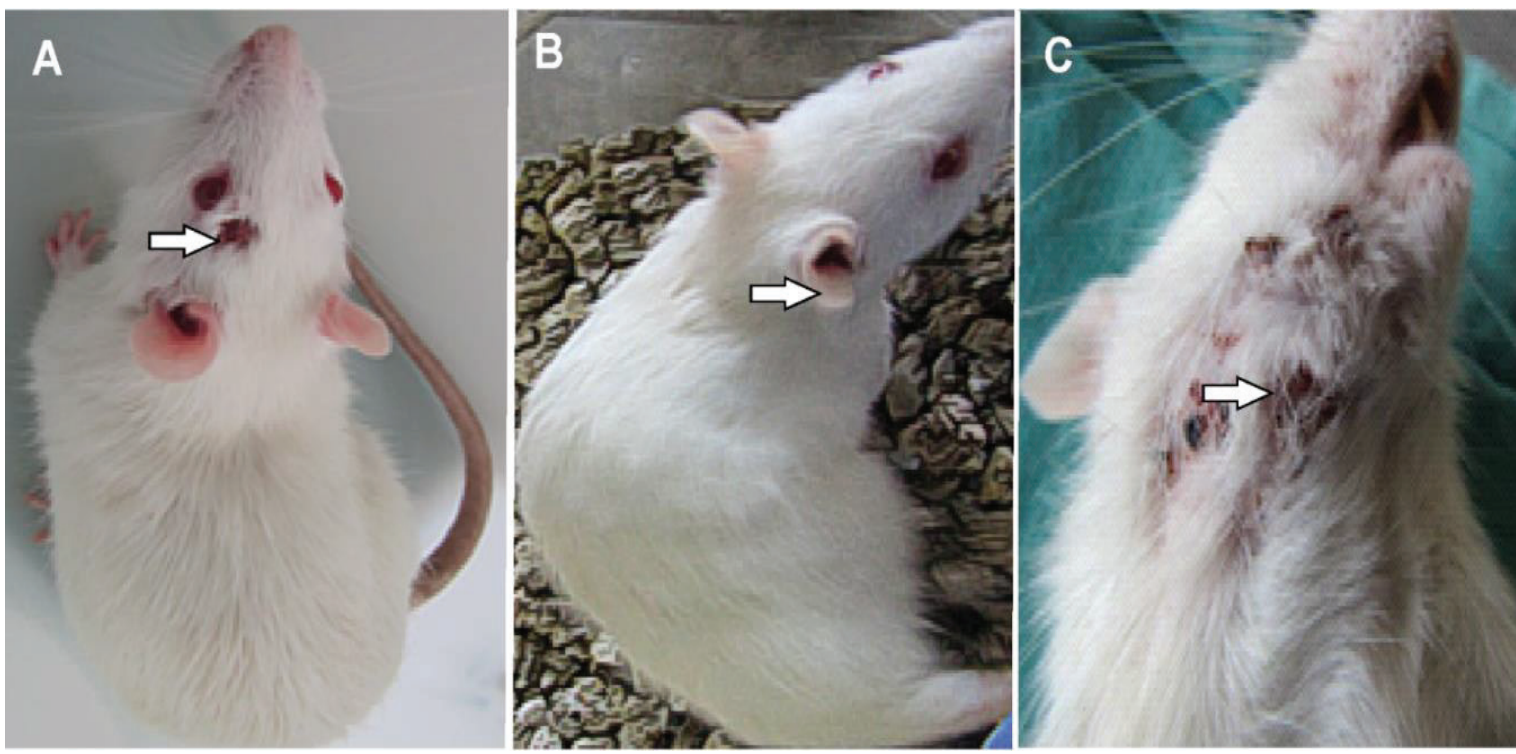

Fig. 1A: Clinical signs observed in rats during the experiment with wounds above the eye. Fig. 1B: Clinical signs observed in rats during the experiment with pale ears. Fig. 1C: Clinical signs observed in rats during the experiment with wounds on the neck. 
The results of trace metal concentrations present in livers and kidneys are indicated in Table 5. The kidney concentrations of As ranged from $0.02-9.59 \mathrm{mg} / \mathrm{kg} ; \mathrm{Cu} 0.08-12.05 \mathrm{mg} /$ $\mathrm{kg}$; Mn 0.04-0.14 mg/kg and Zn 0.20-0.28 mg/kg. In addition, the concentration of $\mathrm{As}$ and $\mathrm{Cu}$ in kidneys collected from site S2 was higher compared to rats fed with extracts of grasses collected from site S1 and tap water (C).

Trace metal concentration in kidneys and livers generally followed the order $\mathrm{Cu}>\mathrm{Zn}>\mathrm{Mn}>$ As. The liver concentration of $\mathrm{Cu}$ ranged from $3.63-3.86 \mathrm{mg} / \mathrm{kg}$; $\mathrm{Mn} 0.16-0.29 \mathrm{mg} / \mathrm{kg}$ and $\mathrm{Zn} 1.19-1.33 \mathrm{mg} / \mathrm{kg}$, but the concentration of As in livers of rats' groups were all below the detection limit. The trace metal in the liver was higher than in the kidneys of these rats.

\section{Enzyme Activities in the Organs}

Liver enzyme activity is presented in Table 6. The differences in liver enzyme activity from the blood serum of the rats were not significant $(\mathrm{p}>0.05)$ as an indicator of liver cell injury. The level of alanine transaminase (ALT) in the blood serum of the rats fed with extracts of grasses from sites $\mathrm{S} 1$ and S2 were higher when compared to the control group. The activity of aspartate transaminase (AST) in the blood serum of the rats fed with grass extracts from the mining areas (S1 and S2) were extremely high when compared to the control group.

The antioxidant activity (CAT, SOD and GSH) are presented in Table 7. The superoxide (SOD), catalase (CAT) and glutathione $(\mathrm{GSH})$ activity in kidneys of the rats fed with extracts of grasses collected from sites S1 and S2 was higher compared to the control (C) group. The kidney antioxidant activities between the groups were significant $(\mathrm{p}<0.05)$. The values of GSH, SOD and CAT for rats fed with extracts of grasses collected from site S2 and control, followed the sequence GSH $>$ SOD $>$ CAT.

Table 3: Daily intake volumes of rats during the study period

\begin{tabular}{|llllll|}
\hline \multirow{2}{*}{ Groups } & \multicolumn{4}{c|}{ Volume of grass extract $(\mathrm{mL})$ per day over one week } \\
\cline { 2 - 6 } & Week 1* & Week 2* & Week 3* & Week 4* & Week 5* \\
\hline S1 & $38.13 \pm 0.52$ & $37.93 \pm 0.51$ & $33.55 \pm 1.39$ & $34.09 \pm 1.46$ & $31.75 \pm 1.46$ \\
S2 & $37.46 \pm 0.85$ & $37.60 \pm 1.02$ & $34.86 \pm 2.69$ & $34.94 \pm 1.59$ & $32.91 \pm 3.31$ \\
C & $36.59 \pm 2.00$ & $35.95 \pm 2.81$ & $36.06 \pm 2.75$ & $36.80 \pm 1.07$ & $35.92 \pm 1.59$ \\
\hline
\end{tabular}

Grass extracts from Site 1 (S1); Site 2 (S2); and control (C)

*Significance of comparison means by ANOVA is indicated by $(\mathrm{p}<0.05)$

Table 4: Mean concentration of trace metals in the spleen of the rats fed with grasses extract and tap water.

\begin{tabular}{|lllllll|}
\hline \multirow{2}{*}{ Groups } & \multicolumn{5}{c|}{ Trace metals $(\mathrm{mg} / \mathrm{kg})$} \\
\cline { 2 - 6 } & $\mathrm{As} *$ & $\mathrm{Cu}$ & $\mathrm{Hg}$ & $\mathrm{Pb} *$ & $\mathrm{Mn} *$ & $\mathrm{Zn}$ \\
\hline $\mathrm{S} 1$ & $0.86 \pm 0.11$ & $8.18 \pm 0.03$ & $0.41 \pm 0.02$ & $0.50 \pm 0.0$ & $1.28 \pm 0.03$ & $79.43 \pm 4.10$ \\
$\mathrm{~S} 2$ & $1.11 \pm 0.11$ & $7.03 \pm 0.13$ & $1.33 \pm 0.33$ & $0.53 \pm 0.02$ & $1.31 \pm 0.44$ & $86.37 \pm 3.21$ \\
$\mathrm{C}$ & $0.69 \pm 0.02$ & $5.93 \pm 0.14$ & $0.18 \pm 0.02$ & $0.41 \pm 0.01$ & $0.68 \pm 0.01$ & $63.22 \pm 2.11$ \\
\hline
\end{tabular}

Grass extracts from Site 1 (S1); Site 2 (S2); and control (C)

*Significance of comparison means by ANOVA is indicated by $(\mathrm{p}<0.05)$

Table 5: Mean concentration of trace metals in the kidney and liver of rats.

\begin{tabular}{|c|c|c|c|c|c|c|}
\hline \multirow{3}{*}{$\begin{array}{l}\text { Trace metals } \\
(\mathrm{mg} / \mathrm{kg})\end{array}$} & \multicolumn{6}{|c|}{ Groups } \\
\hline & \multicolumn{2}{|l|}{ S1 } & \multicolumn{2}{|l|}{ S2 } & \multicolumn{2}{|l|}{ Control } \\
\hline & Kidney & Liver & Kidney & Liver & Kidney & Liver \\
\hline As* & 0.04 & $<\mathrm{DL}$ & 9.59 & $<\mathrm{DL}$ & 0.02 & $<\mathrm{DL}$ \\
\hline $\mathrm{Cu}^{* *}$ & 0.12 & 3.71 & 12.05 & 3.86 & 0.08 & 3.63 \\
\hline $\mathrm{Mn} * *$ & 0.14 & 0.29 & $<\mathrm{DL}$ & 0.17 & 0.04 & 0.16 \\
\hline $\mathrm{Zn} * *$ & 0.28 & 1.32 & $<\mathrm{DL}$ & 1.33 & 0.20 & 1.19 \\
\hline
\end{tabular}

Grass extracts from Site 1 (S1); Site 2 (S2); and tap water (C)

*Significance of comparison means by ANOVA is indicated by $(\mathrm{p}<0.05)$

** No significance of comparison means by ANOVA is indicated by $(\mathrm{p}>0.05)$

$<$ DL: Detection limit 
Transmission electron microscopy (TEM) provided valuable ultrastructural information on the pathological changes observed in the kidney glomerulus (Fig. 2).

\section{DISCUSSION}

The concentrations of trace metals such as $\mathrm{Zn}, \mathrm{Mn}$ and $\mathrm{Cu}$ were high in both the grasses and pellets used in this study. Previous studies showed that plants can bioaccumulate trace metals from the soil and may have a high concentration of toxic trace metals (Olowoyo et al. 2013, Lion et al. 2016). The concentration of $\mathrm{Zn}$ in Urochloa mosambicensis (S1) and rat pellets in this study was higher than the permissible limit set by FAO/WHO (2011) which is $60 \mathrm{mg} / \mathrm{kg}$ (Bvenura \& Afolayan 2012). However, the high concentration of $\mathrm{Zn}$ and $\mathrm{Mn}$ in $U$. mosambicensis from site $\mathrm{S} 1$ may be due to the translocation factor and bioaccumulation factor of this grass from a polluted area (Lion et al. 2016). The ingestion of food containing a high concentration of $\mathrm{Zn}$ and $\mathrm{Mn}$ have been reported to cause anaemia, reduced bone formation, kidney stones and pneumonia (USDHH 2012, Yogesh et al. 2013).

The concentration of trace metals such as $\mathrm{Mn}$ and $\mathrm{Cu}$ in tap water was higher than the acceptable limit set by WHO (2011). The presence of high trace metal concentration in the extracts may thus be due to combining grasses and tap water when preparing the extracts. Moreover, $\mathrm{Mn}, \mathrm{Zn}$ and $\mathrm{Cu}$ affect the blood, kidneys, lungs, urinary tract, stomach and skin (Jarup 2003, USDHHS 2012, Yogesh et al. 2013).

Clinical signs such as fur loss and itching, which are clear indicators of acute pain in the rats, were observed in the experimental groups during the study. Similar results were obtained in the study conducted by Alimba et al. (2012) where rats treated with municipal leachates suffered loss of appetite, hair loss, diarrhoea and signs of ungroomed hair as symptoms of immune dysfunction. The study by Jarup (2003) noted that the changes in skin lesions and presentation of gastrointestinal indicators could be due to high trace metal consumption from the grass extracts thus leading to changes in the immune responses of the rats.

In an earlier study, Rubio et al. (2008) reported on significantly higher concentrations of toxic metals that were bio-accumulated in spleen rather than other organs, although some toxic metals were only detected in the spleen. A related study by Naven et al. (2017) investigated the trace metal content of spleen from rats exposed to chronic fasciolosis and basic zinc-copper, which showed an increase in the concentration of trace metals when the immune system of the animal was compromised similarly to those infected with chronic fascioli, and other infections (Tarantino et al. 2013).

The recorded concentrations of toxic trace metals in the spleen of treated rats during our study were significantly higher than the recommended limit set by National Health and Research Medical Council (NHRMC) and the World Health Organization (WHO). The recommended limit of lead $(\mathrm{Pb})$, mercury $(\mathrm{Hg})$ and arsenic (As) in organs of a healthy body is reported as $0.05 \mathrm{mg} / \mathrm{kg}, 0.2 \mathrm{mg} / \mathrm{kg}$ and $0.5 \mathrm{mg} / \mathrm{kg}$ respectively (Norouzi et al. 2017). The studies conducted by Arantes et al. (2015) and Kuang et al. (2016) proposed that the changes observed in the spleen may be due to the toxic level of $\mathrm{Pb}$ and $\mathrm{Hg}$ accumulation in the visceral organs.

Table 6: Liver enzyme activity

\begin{tabular}{|lll|}
\hline \multirow{2}{*}{ Groups } & \multicolumn{2}{c|}{ Liver Enzymes (IU/L) } \\
\cline { 2 - 3 } & ALT** & AST** \\
\hline S1 & $65.67 \pm 23.83$ & $166.11 \pm 35.83$ \\
S2 & $67.90 \pm 18.74$ & $254.40 \pm 99.23$ \\
Control & $64.90 \pm 15.50$ & $142.00 \pm 26.09$ \\
\hline
\end{tabular}

Grass extracts from Site 1 (S1); Site 2 (S2); and tap water (C)

**No significant difference in the values obtained for liver enzymes test in blood serum $(\mathrm{p}>0.05)$

Table 7: Kidney antioxidant enzyme activities in rats fed with grass extracts and tap water.

\begin{tabular}{|llll|}
\hline \multirow{2}{*}{ Groups } & \multicolumn{3}{c|}{ Anti-oxidant Enzymes } \\
\cline { 2 - 4 } & $\mathrm{SOD}^{*}(\mathrm{pg} / \mathrm{mL})$ & $\mathrm{CAT}^{*}(\mathrm{ng} / \mathrm{mL})$ & $\mathrm{GSH}(\mu \mathrm{g} / \mathrm{mL})$ \\
\hline S1 & $3.46 \pm 0.06$ & $3.46 \pm 0.09$ & $3.24 \pm 0.16$ \\
S2 & $3.13 \pm 0.59$ & $3.06 \pm 0.65$ & $3.22 \pm 0.17$ \\
Control & $2.68 \pm 1.64$ & $2.60 \pm 0.43$ & $3.08 \pm 0.15$ \\
\hline
\end{tabular}

Grass extracts from Site 1 (S1); Site 2 (S2); and tap water (C)

* Significant difference in the values obtained for kidneys antioxidant activities from different groups $(\mathrm{p}<0.05)$. 


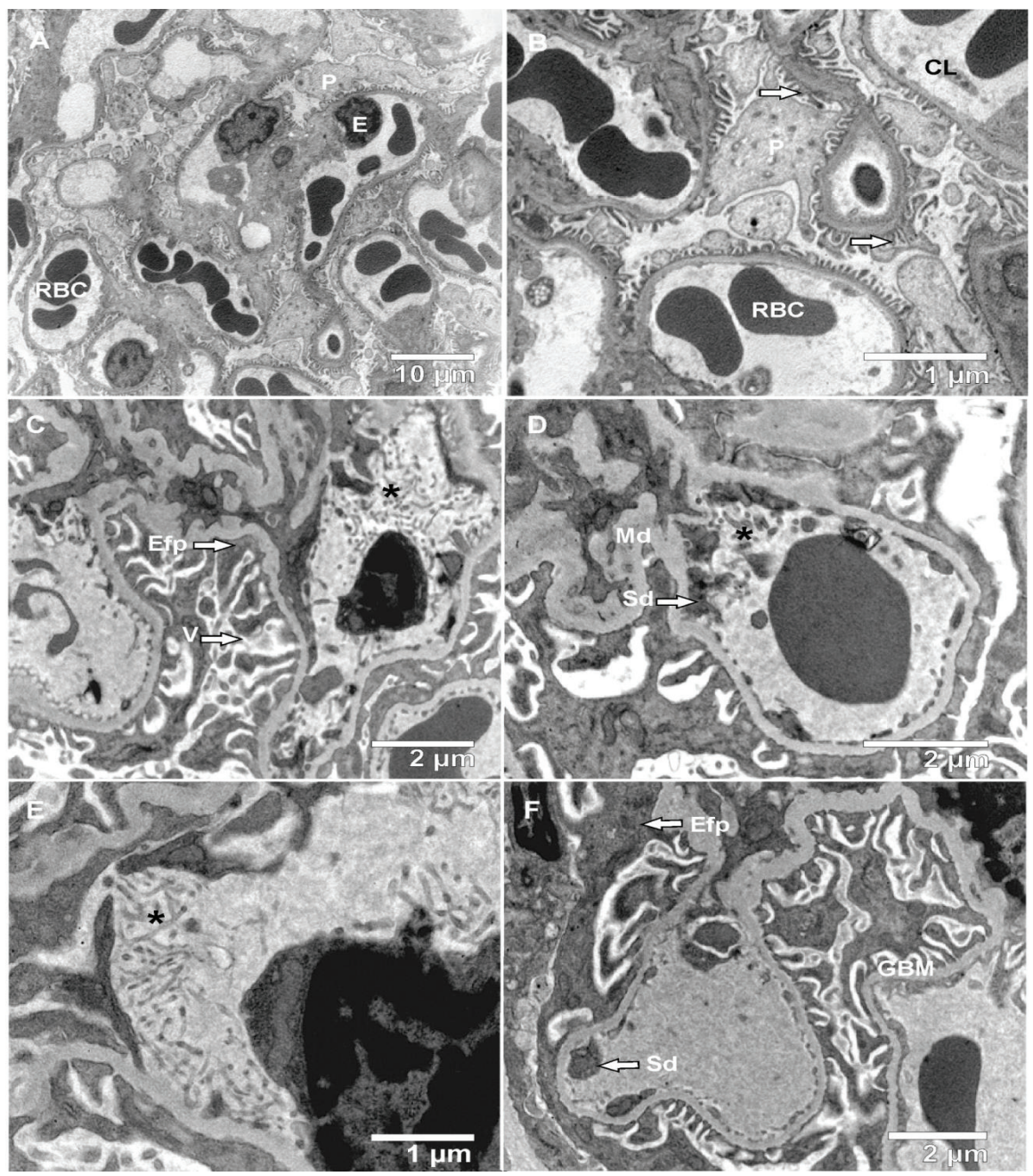

Fig. 2A and B: Electron micrographs of kidney glomeruli control with red blood cells (RBC), capillary lumen (CL) with endothelial cells (E) and podocytes (P) with well-developed fenestrae (arrows); Fig. 2C and D: Rats fed with grass extracts from mining area S1 showing mesangial deposits (Md), villous hypertrophy (V), sub-endothelial deposit (Sd), effaced foot process of podocytes (Efp) and tactoids (*); Fig. 2E and F: The glomerular basement membrane (GBM), tactoids (*), effaced foot process (Efp) and sub-endothelial deposits (Sd).

This study supported the findings of Barbier et al. (2005) which identified kidneys as a secondary bioaccumulator of trace metals, possibly due to their re-absorption potential. The accumulation of $\mathrm{As}$ and $\mathrm{Cu}$ in kidney tissues of rats fed with grass extracts collected from site S2, is associated with an increase in the level of ALT and AST activities. The recorded trace metal concentrations in the kidneys during this study may affect the metabolic process and transportation of enzymes to the kidney tubules (Pereira et al. 2006) and possibly damage the internal organs (Ajayi et al. 2011). The increased activity of AST in all the groups may be an indication of hepatocellular damage as corroborated by Markiewicz-Gorka et al. (2015) when exposing rats to toxic concentrations of lead, cadmium and manganese. The normal activity of ALT in all the groups may result from elevated AST since ALT allows the AST level to initially peak due to oxygen starvation (Hall \& Cash 2012).

Our study indicates decreased enzymatic activity of CAT and SOD in all the groups, which may be due to apoptosis, proliferation of cells, cell differentiation or maintenance of redox-sensitive signal transduction pathways (Weydert \& Cullen 2009). The Markiewicz-Gorka et al. (2015) similarly reports low SOD and CAT activities in rats exposed to trace metals such as lead and manganese. The observed study by the increase of GSH from our study may be due to kidney necrosis as corroborated by Purucker et al. (1995) where an increase of GSH was attributed to renal dysfunction and liver cirrhosis. Our results obtained for GSH corroborate 
the work of Scaduto et al. (1988) where increased GSH caused ischemia-induced renal dysfunction and renal failure (Sindhu et al. 2005) resulting in various complications such as anaemia, impaired immunity and abnormalities in haemostasis. It has further been shown that long-term exposure of trace metals in rats can also cause chronic or acute renal dysfunction (Soewu et al. 2014).

Pathology changes in the kidney glomerulus during our investigation may be due to the concentration of trace metals absorbed during experimental exposure. Epithelial cells of the glomerulus also showed the increased villous formation of the podocytes, which caused hypertrophy within the lumen ultimately leading to malfunctioning of these cells (Tobar et al. 2013). The tactoids observed in the capillary lumen signify immunotactoid glomerulopathy also known as a rare glomerular disease (Nasr et al. 2012). This disease is a condition whereby antibodies are deposited abnormally in the kidneys during filtration of blood to produce urine with waste products (UNC Kidney Center 2015).

Acute kidney injury can decrease the rate of glomerular filtration, which fails to eliminate environmental toxins and metabolic waste from the body (Orr \& Bridges 2017). Affaced foot processes of podocytes and sub-endothelial deposits (Fig. 2E \& 2F) have been reported to be the characteristic of proteinuric renal disease (Degeens et al. 2008), where damaged renal tubular cells present as a sign of acute kidney injury (Lee et al. 2012). Histopathology and electron microscopical examination of tissues can identify the end stages of organ toxicity and lesions caused by xenobiotics such as trace elements (Orr \& Bridges 2017).

\section{CONCLUSION}

From the present study, the toxicity impact of the trace metals was linked to accelerated weakening of the immune system, causing allergies that negatively affected the normal functioning of the organs of the test animals. It was also noted that the kidney antioxidant activity of the experimental animals was largely impaired as a result of the high level of trace metals found in the kidney. Besides, the mesangial deposits in the kidney of the rats fed with polluted grass resulted in proliferative glomerulonephritis with the visible formation of lesions. High absorption of trace metals in the liver adversely affected the blood serum ALT and AST activities by increasing the serum activity, an indicator of liver damage. Some trace metals found in organs such as the liver, kidney, and spleen of control rats was possibly from the pellets and tap water as recorded in this study. Consumption of polluted grasses as a whole as demonstrated in previous studies or as extracts as demonstrated in the present study have a significant effect on the organs of mammals hence consumption or usage of plant materials harvested from polluted sites should be discouraged as this may pose a serious health risk.

\section{ACKNOWLEDGEMENT}

The authors would like to acknowledge the support from the staff of Biology and Physiology Department, Sefako Makgatho Health Sciences University, and also acknowledge the financial support received from NRF, South Africa

\section{REFERENCES}

Ajayi, O.A., Idowu, A.B., Eromosele, C.O., Dedeke G.A. and Ademolu, K.O. 2011. Distribution and effect of some heavy metals in selected organs and tissues of albino rats exposed to vehicular exhaust fumes. Proceedings of the Environmental Management Conference, Federal University of Agriculture, Abeokuta, Nigeria.

Alimba, C.G., Bakare, A.A. and Aina, O.O. 2012. Liver and kidney dysfunction in wistar rats exposed to municipal landfill leachate. Journal of Resources and Environment 2(4): 150-163.

Arantes, F.P., Savassi, L.A., Santos, H.B., Gomes, M.V.T. and Bazzoli, N. 2015. Bioaccumulation of mercury, cadmium, zinc, chromium and lead in muscle, liver and spleen tissues of a large commercially valuable catfish species from Brazil. Annals of the Brazilian Academy of Sciences, 88(1): 137-147.

Baby, J., Raj, J., Biby, E.T., Sankarganesh, P. Jeevitha, M.V., Ajisha, S.U. and Rajanm S.S. 2010. Toxic effect of heavy metals on the aquatic environment. International Journal of Biological and Chemical Sciences, 4(4): 939-952.

Barbier, O., Jacquillet, G., Tauc, M., Cougnom, M. and Poujeol, P. 2005. Effect of heavy metals on and handling by the kidney. Nephron Physiology Journal, 99: 105-110.

Bvenura, C. and Afolayan, A.J. 2012. Heavy metal contamination of vegetables cultivated in home gardens in the Eastern Cape. South African Journal of Science, 108(9/8): 1-6.

Deegens, J.K.J., Dijkman, H.B.P.M., Born, G.F., Steenbergen, E.J., van den Berg, J.G., Weening, J.J. and Wetzels, J.F. 2008. Podocyte foot process effacement as a diagnostic tool in focal segmental glomerulosclerosis. Kidney International Journal, 74(1): 158-1576.

Durkalec, M., Szkoda, J, Kolacz, R., Opalinski, S., Nawrocka, A. and Zmudzki, J. 2014. Bioaccumulation of lead, cadmium, and mercury in roe deer and wild boars from areas with different levels of toxic metal pollution. International Journal of Environmental Research, 9(1): 205-212.

Food and Agricultural Organization/World Health Organization (FAO/ WHO). 2011. Joint FAO/WHO food standards programme codex committee on contaminants in foods. http://www.fao.org/tempref/codex/Meetings/CCCF/CCCF5/cf05_INF.pdf. Retrieved on 15/03/2019.

Hall, P. and Cash, J. 2012. What is the real function of the liver 'function' tests? Ulster Medical Society, 81(1): 30-36.

Hu, H., Jin, Q. and Kavan, P. 2014. A study of heavy metal pollution in China: Current status, pollution-control policies and counter measures. Sustainability, 6: 5820-5838.

Jan, A.T., Azam, M., Siddiqui, K., Ali, A., Choi, I. and Haq, Q.M.R. 2015. Heavy metals and human health: mechanistic insight into toxicity and counter defence system of antioxidants. International Journal of Molecular Sciences, 16: 29592-29630.

Jarup, L. 2003. Hazards of heavy metals contamination. British Medical Bulletin, 68: 167-182.

Kuang, P., Deng, H., Cui, H., Chen, L., Fang, J., Zuo, Z., Den, J., Wang, $\mathrm{X}$. and Zhao, L. 2016. Sodium fluoride $(\mathrm{NaF})$ causes toxic effects on splenic development in mice. Oncotarget, 8(3): 4703-4717. 
Lee, J.Y., Eom, M., Yang, Y.W., Han, B.G., Choi, S.O. and Kim, J.S. 2012. Acute kidney injury by Arsine poisoning: The ultrastructural pathology of the kidney. Renal Failure, 35(2): 299-301.

Li, Q., Liu, H., Alattar, M., Jiang, S., Ham, J., Ma, Y. and Jiang, C. 2015. The preferential accumulation of heavy metals in different tissues following frequent respiratory exposure to PM2.5 in rats. Scientific Report, 5(16936): 1-8.

Lion, G.N., Olowoyo, J.O. and Modise, T.A. 2016. Trace metals bioaccumulation potentials of three indigenous grasses grown on polluted soils collected around mining areas in Pretoria, South Africa. West African Journal of Applied Ecology, 24(1): 43- 51.

Lusco, M.A., Fogo, A.B., Najafian, B. and Alpers, C.E. 2016. Proliferative glomerulonephritis with monoclonal immunoglobulin deposits. Atlas of Renal Pathology ii, 67(3): e13-e15.

Markiewicz- Gorka, I., Januszewska, L., Michalak, A., Prokopowicz, A., Januszewska, E., Pawlas, N. and Pawlas, K. 2015. Effects of chronic exposure to lead, cadmium, and manganese mixtures on oxidative stress in rat liver and heart. Arh. Hig. Rada Toksikol., 66: 21-62.

Mohapatra, A.K., Kumari, P. and Datta, S. 2009. Cadmium induced histopathological changes in the stomach and small intestine of swiss albino mice, Mus museulus. Journal of Applied and Natural Sciences, 1(2): 253-257.

Mohod, C.V. and Dhote, J. 2013. Review of heavy metals in drinking water and their effect on human health. International Journal of Innovative Research in Science, Engineering and Technology, 2(7): 2992-2996.

Moreira, J.C., Silva, A.L.O., Barrocas, P.R.G. and Jacob, S.C. 2005. Dietary intake and health effects of selected toxic elements. Brazil Journal of Plant Physiology, 17(1): 79-93.

Nasr, S.H., Fidler, M.E., Cornell, L.D., Leung, N., Cosio, F.G., Sheikh, S.S., Amir, A.A., Vrana, J.A., Theis, J.D., Dogan, A. and Sethi, S. 2012. Immunotactoid glomerulopathy: Clinicopathologic and proteomic study. Nephrology Dialysis Transplantation, 27(11): 4137-4146.

National Research Council (NRC) 2000. Copper in drinking water. Washington, D.C.: National Academies Press (US).

Naven, V., Vladov, I., Gabrashanka, M., Kandil, O.M, Noha, M.F. and Sedky, H.D. 2017. Rat spleen trace element contents under combined effect of chronic fasciolis and basic zinc-copper compound. Accounts of the Bulgarian Academy of Sciences, 70(8): 1115-1120.

Nazir, R., Khan, M., Masab, M., Rehman, H.U.R., Rauf, N.U.R., Shahab, S., Ameer, N., Sajed, M., Ulah, M., Rafeeq, M. and Shaheen, Z. 2015. Accumulation of heavy metals ( $\mathrm{Ni}, \mathrm{Cu}, \mathrm{Cd}, \mathrm{Cr}, \mathrm{Pb}, \mathrm{Zn}, \mathrm{Fe}$ ) in the soil, water and plants and analysis of physic-chemical parameters of soil and water collected from Tanda Dam Kohat. Journal of Pharmaceutical Sciences and Research, 7(3): 89-97.

Norouzi, M., Bagheri. T.M., Ghodrati, S.H. and Amirjanati, A. 2017. Toxic heavy metal concentration in soft tissues of gray mullet Liza aurata (Mugilidae: Perciformes) during the sexual maturity and sexual res. Iran Journal of Fish Sciences, 16(3): 920-934.

Okonkwo, J.O, Moja, S.J. and Forbes, P. 2009. Manganese levels and chemical fraction in street dust in South Africa. International Journal of Environmental Pollution, 36(4): 350-366.

Olowoyo, J.O., Van Heerden, E. and Fischer, J.L. 2011. Trace element concentrations from lichen transplants in Pretoria, South Africa. Environmental Science and Pollution Research, 18(4): 663-668.

Olowoyo, J.O., van Heerden, E. and Fischer, J. 2013. Trace metals concentrations in soil from different sites in Pretoria, South Africa. Sustainable Environment Research, 23(1): 93.

Orr, S.E. and Bridges, C.C. 2017. Chronic kidney disease and exposure to nephrotoxic metal. International Journal of Molecular Sciences, 18: 1-35.

Parveen, P., Abbasi, A.M., Shaheen, N. and Shah, M.H. 2017. Accumulation of selected metals in the fruits of medicinal plants grown in urban environment of Islamabad, Pakistan. Arabian Journal of Chemistry, 13(1): 308-317.
Pereira, R., Pereira, M.L., Ribeira, R. and Goncalves, F. 2006. Tissues, hair residues, histopathology in wild rats (Rattus rattus L.), and Algerian mice (Mus spretus Lataste) from an abandoned mine area (Southeast Portugal). Environmental Pollution, 139: 561-575.

Purucker, E., Wernze, W. and Krandik, G. 1995. Glutathione in plasma, liver, and kidney in the development of $\mathrm{CCl}_{4}$-induced cirrhosis of the rat. Research in Experimental Medicine, 195(4): 193-199.

Qu, C., Ma, Z., Jin, Y., Liu, Y., Bi, J. and Huang, L. 2012. Human exposure pathways of heavy metals in a lead-zinc mining area, Jiangsu Province China. Plos ONE, 7(11): e46793.

Rubio, J.C., Garcia-Alonso, M.C., Alonso, C., Alobera, M.A., Clemente, C., Munuera, L. and Escudero, M.L. 2008. Determination of metallic traces in kidneys, livers, lungs and spleens of rats with metallic implants after a long implantation time. Journal of Materials Science: Materials in Medicine, 19: 369-375.

Scaduto, R.C., Gattone, V.H., Grotyohann, L.W., Werts, J. and Martin, L.F. 1988. Effect of altered glutathione content on renal ischemic injury. American Journal of Physiology, 255 (5pt2): 911-921.

Sindhu, R.K., Ehdaie, A., Farmand, F., Dhaliwa, K.K., Nguyen, T., Zhan, C.D., Roberts, C.K. and Vaziri, N.D. 2005. Expression of catalase and glutathione peroxidase in renal insufficiency. Biochemica et Biophysica Acta, 1743: 86-92.

Soewu, D.A., Agbolade, O.M., Oladunjoye, R.Y. and Ayodele I.A. 2014. Bioaccumulation of heavy metals in cane rat (Thryonomys swinderianus) in Ogun State, Nigeria. Journal of Toxicology and Environmental Health Sciences, 6(8): $154-160$.

Stankovic, S., Kalaba, P. and Stankovic, A.R. 2014. Biota as toxic metal indicators. Environmental Chemistry Letters, 8: 472-481.

Tarantino, G., Scalera, A. and Finelli, C. 2013. Liver-axis: Intersection between immunity, infections and metabolism. World Journal of Gastroenterology, 19(23): 3534-3542.

Tembeni, B., Oyedej, O.O., Ejidike, I.P. and Oyedeji, A.O. 2016. Evaluation of trace metal profile in Cymbogon validus and Hyparrhenia hirta used as traditional herbs from environmentally diverse region of Komga, South Africa. Journal of Analytical Methods in Chemistry. Article ID 9293165, 8p

Tobar, A., Ori, Y., Benchetrit, S., Milo, G., Herman-Edelstein, M., Zingerman, B., Lev, N., Gafter, U. and Chagmac, A. 2013. Proximal tubular hypertrophy and enlarged glomerular and proximal tubular urinary space in obese subjects with proteinuria. PLos One, 25: 8(9): e75547.

UNC Kidney Center. 2015. Immunotactoid glomerulopathy. http://www. unckidneycenter.org/. Retrieved on 2/11/2018.

U.S. Department of health and human services (USDHHS). 2012. Toxicological Profile for Manganese. http:// www.atsdr.cdc.gov. Retrieved on $2 / 11 / 2018$.

Wang, Y., Ou, Y., Liu, Y., Xie, Q., Liu, Q.F., Wu, Q., Fan, T.Q., Yan, L.L. and Wang, J.Y. 2012. Correlations of trace element levels in diet, blood, urine, and feces in the Chinese male. Biological Trace Elements of Research, 145: 127-135.

Weydert, C.J. and Cullen, J.J. 2009. Measurement of superoxide dismutase, catalase and glutathione peroxidase in cultured cells and tissue. National protocol, 5(1): 51-66.

WHO, 2011. Manganese in drinking water. Background document for development of WHO guidelines for drinking water quality. http:// www.who.int/water_sanitation_health/dwq/chemicals/manganese.pdf. Retrieved on 22/11/2016.

Writer, S. 2016. The most polluted city in South Africa is not where you expect. Business Tech. Newsletter. May 12, 2016.

Yogesh, P.P., Sachin, H.P., Sharu, J. and Jitendra, S.K. 2013. Biochemistry of metal absorption in human body: Reference to check impact of nano particles on human being. International Journal of Scientific and Research Publications, 3(4): 1-5.

Zhai, Q., Naarbad A. and Chen, W. 2015. Dietary strategies for the treatment of cadmium and lead toxicity. Nutrients 7: 552-571. 